\title{
In vitro cytotoxicity of superparamagnetic iron oxide nanoparticles on neuronal and glial cells. Evaluation of nanoparticle interference with viability tests
}

\author{
Carla Costa ${ }^{a, b *}$, Fátima Brandão ${ }^{a}$, Maria João Bessa ${ }^{a}$, Solange Costa ${ }^{a, b}$, \\ Vanessa Valdiglesias', Gözde Kiliç, ${ }^{c, d}$, Natalia Fernández-Bertólez, ${ }^{c, d}$, \\ Pedro Quaresma ${ }^{e}$, Eulália Pereira ${ }^{e}$, Eduardo Pásaro ${ }^{c}$, Blanca Laffon ${ }^{c}$ \\ and João Paulo Teixeira ${ }^{a, b}$
}

\begin{abstract}
Superparamagnetic iron oxide nanoparticles (ION) have attracted great interest for use in several biomedical fields. In general, they are considered biocompatible, but little is known of their effects on the human nervous system. The main objective of this work was to evaluate the cytotoxicity of two ION (magnetite), coated with silica and oleic acid, previously determining the possible interference of the ION with the methodological procedures to assure the reliability of the results obtained. Human neuroblastoma SHSY5Y and glioblastoma A172 cells were exposed to different concentrations of ION (5-300 $\left.\mu \mathrm{g} \mathrm{ml}{ }^{-1}\right)$, prepared in complete and serum-free cell culture medium for three exposure times (3, 6 and $24 \mathrm{~h})$. Cytotoxicity was evaluated by means of the MTT, neutral red uptake and alamar blue assays. Characterization of the main physical-chemical properties of the ION tested was also performed. Results demonstrated that both ION could significantly alter absorbance readings. To reduce these interferences, protocols were modified by introducing additional washing steps and cell-free systems. Significant decreases in cell viability were observed for both cell lines in specific conditions by all assays. In general, oleic acid-coated ION were less cytotoxic than silica-coated ION; besides, a serum-protective effect was observed for both ION studied and cell lines. These results contribute to increase the knowledge of the potential harmful effects of ION on the human nervous system. Understanding these effects is essential to establish satisfactory regulatory policies on the safe use of magnetite nanoparticles in biomedical applications. Copyright $\odot 2015$ John Wiley \& Sons, Ltd.
\end{abstract}

Keywords: cytotoxicity; glioblastoma cells; magnetite; neuroblastoma cells; oleic acid-coated iron oxide nanoparticles; silica-coated iron oxide nanoparticles

\section{Introduction}

Nanotechnology is currently one of the fastest-growing industries on the planet, and its development is accompanied by promises of substantial benefits that will have significant economic and scientific impacts (Singh et al., 2009). With the rapid expansion of the nanotechnology industry, there are increasing concerns as to the potential adverse human health and environmental effects that the production and subsequent exposure to nanoparticles might pose (Clift et al., 2011).

Superparamagnetic iron oxide nanoparticles (ION) have attracted considerable interest due to their excellent magnetic properties, biocompatibility and biodegradability. Recent advances improved the magnetic and physicochemical properties of ION broadening their potential applications (Stephen et al., 2011). These magnetic nanoparticles are promising contrast agents for magnetic resonance imaging and are a major class of nanoscale material currently under extensive development for improved diagnosis and treatment of a wide range of diseases, including cancer, cardiovascular disease and neurological disease (Xie and Jon, 2012). In general, ION are considered biocompatible
(Kunzmann et al., 2011). Nevertheless, little is known on the effects of ION on the human nervous system as few studies were published using human neural cell lines and results obtained were

\footnotetext{
*Correspondence to: Carla Costa, Department of Environmental Health, Portuguese National Institute of Health, Rua Alexandre Herculano, 321, 4000-055 Porto, Portugal.

E-mail: cstcosta@gmail.com
}

${ }^{a}$ Department of Environmental Health, Portuguese National Institute of Health, Porto, Portugal

${ }^{b}$ EPIUnit - Institute of Public Health, University of Porto, Porto, Portugal

'DICOMOSA Group, Department of Psychology, Area of Psychobiology, Universidade da Coruna, Campus Elviña s $\mathrm{n}, \mathrm{A}$ Coruña, Spain

${ }^{d}$ Department of Cell and Molecular Biology, University of A Coruña, Campus de A Zapateira s/n, A Coruña, Spain

${ }^{e}$ REQUIMTE, Departamento de Química e Bioquímica, Faculdade de Ciências da Universidade do Porto, Porto, Portugal 
not consistent (Chen et al., 2012; Kenzaoui et al., 2012; Valdiglesias et al., 2015; Xiang et al., 2003).

For a complete risk assessment of nanoparticles, it is necessary not only to address the level of exposure to these materials but also to determine their potential hazard (Landsiedel et al., 2010). In vitro cytotoxicity testing constitutes the first step in the assessment of possible interactions between these particles and biological processes. Among the most commonly used assays to evaluate in vitro cell cytotoxicity due to nanoparticle exposure one may find 3-(4,5-dimethylthiazol-2yl)-2,5-diphenyltetrazolium bromide (MTT), alamar blue (AB) and neutral red uptake (NRU) assays. These are all colorimetric assays but differ in principle and therefore offer complementary information on mechanistic processes of cytotoxicity. The MTT assay is based on the intracellular reduction of the MTT reagent to insoluble formazan by $\mathrm{NAD}(\mathrm{P}) \mathrm{H}$-dependent enzymes (Berridge et al., 1996). Rezasurin (reagent used in the AB assay) can be reduced also by cytochromes and other enzymes located in the cytoplasm changing from indigo blue (oxidized: resazurin) to a pink species (reduced: resorufin) (Rampersad, 2012). The NRU assay is based on the ability of viable cells to incorporate and bind the supravital dye NR in the lysosomes. The uptake of NR depends on the cell capacity to maintain $\mathrm{pH}$ gradients, through the production of ATP, and therefore the amount of retained dye is proportional to the number of viable cells. In addition, the uptake of NR by viable cells can be modified by alterations in cell surface or lysosomal membranes (Repetto et al., 2008).

Previous studies on ION cytotoxicity have been conducted in different cell lines and show conflicting results as some studies showed no alterations on viability (e.g., Dunning et al. [2004] found no significant difference in Schwann cell viability using propidium iodide assay after exposure to dextran-coated ION) while others indicate cell toxicity (e.g., mesenchymal cells showed a decrease in viability after exposure to Endorem ${ }^{\oplus}$ ION by water-soluble tetrazolium salt assay; Babič et al., 2009). A number of factors could be based on these conflicting results. Although differences in the physicochemical characteristics of these nanoparticles, such as size and surface modification, seem to be the main reason for these variations (Hong et al., 2011), inattention to interference of the tested nanoparticles with the experimental procedures can also be responsible for false results (either positive or negative) (Domey et al., 2014). Correct in vitro assessment of nanoparticle cytotoxicity entails a careful choice of the test systems and it should always include the analysis of possible interferences with the optical detection methods and reagents, the ability to convert the substrates and/or the influence on enzymatic activity. Besides, some authors suggest the use of a combinatorial approach to cell viability and cytotoxicity screening by carrying out different assays to monitor nanomaterial cytotoxicity to identify the most meaningful and representative in vitro result (Wörle-Knirsch et al., 2006).

The present study aims to evaluate cytotoxicity of two ION with different coatings (silica and oleic acid coating) on both human neuroblastoma (SHSY5Y) and human glioblastoma (A172) cell lines by using the classical in vitro cytotoxicity assays, MTT, NRU and AB. An in-depth evaluation of all potential interferences, including the absorbance range of the nanoparticles and expected interactions with assay components was also completed to guarantee the reliability of the results obtained.

\section{Materials and methods}

\section{Chemicals}

The MTT (CAS no. 298-93-1), NR dye (CAS no. 553-24-2), rezasurin (CAS no. 62758-13-8) and Triton X-100 (CAS no. 9002-93-1) were purchased from Sigma-Aldrich Co. (Sintra, Portugal) Dimethyl sulfoxide (DMSO; CAS no. 37-68-5), acetic acid ( glacial) 100\% (CAS no. 64-19-7), and ethanol absolute (CAS no. 64-17-5) were bought from Merck KGaA (Darmstadt, Germany). Cell culture media components were all Invitrogen products and purchased from Thermo Fisher Scientific Inc. (Uppsala, Sweden).

\section{Nanoparticle preparation}

Iron oxide nanoparticles coated with silica (S-ION) and oleic acid (OA-ION) were synthesized and prepared as stable water stock suspensions (S-ION $5 \mathrm{mg} \mathrm{ml}^{-1}$ and OA-ION $19 \mathrm{mg} \mathrm{ml}^{-1}$ ) as described by Yi et al. (2006) and Maity and Agrawal (2007), respectively. Before each treatment, a $1 \mathrm{mg} \mathrm{ml}^{-1}$ suspension was prepared in water, complete or incomplete medium and sonicated in water bath for $5 \mathrm{~min}$. Serial dilutions were carried out to obtain the different ION concentrations tested and sonicated in the water bath for an additional 5 min period.

\section{Nanoparticle characterization}

Primary particle size and particle morphology were characterized by monolayer transmission electron microscopy (TEM) using a HITACHI $\mathrm{H}-8100$ microscope equipped with EDS (ThermoNoran; Thermo Scientific, Hitachi, Tokyo, Japan) operated at 200 kV. Images were analyzed using ImageJ public domain software. The average hydrodynamic size and zeta potential of particles in suspension were determined by dynamic light scattering (DLS) and mixed mode measurement phase analysis light scattering, respectively, using a Zetasizer Nano-ZS equipped with $4.0 \mathrm{~mW}, 633 \mathrm{~nm}$ laser (Model ZEN 3600; Malvern Instruments Ltd., Malvern, Worcs, UK).

Photoelectron spectroscopy (XPS) was used to determine particle surface chemistry. The XPS analysis was performed using a ESCALAB 200A, VG Scientific (East Grinstead, UK) with PISCES software for data acquisition and analysis. For analysis, an achromatic Al $(\mathrm{K} \alpha)$ X-ray source (1486.6 eV) operating at $15 \mathrm{kV}$ (300 W) was used, and the spectrometer, calibrated with reference to $\mathrm{Ag}$ $3 \mathrm{~d} 5 / 2(368.27 \mathrm{eV})$, was operated in CAE mode with a pass energy of $20 \mathrm{eV}$ (ROI) and $50 \mathrm{eV}$ (survey). Data acquisition was performed with a pressure lower than $1 \times 10^{-6} \mathrm{~Pa}$. The surface charging effect was corrected using the carbon peak as reference $(285 \mathrm{eV})$. The deconvolution of spectra was performed using the XPSPEAK41 program, in which an adjustment of the peaks was performed using peak fitting with a Gaussian-Lorentzian peak shape and Shirley type background subtraction.

\section{Cell cultures}

Human neuroblastoma SHSY5Y and human glioblastoma A172 cell lines were obtained from the European Collection of Cell Cultures. SHSY5Y was cultured in nutrient mixture EMEM/F12 (1:1) medium with $1 \%$ non-essential amino acids, $1 \%$ antibiotic and antimycotic solution, and supplemented with $10 \%$ heat-inactivated fetal bovine serum. Culture media of the A172 cell line consisted of Dulbecco minimal Eagle's medium (high glucose) with $2 \mathrm{~mm}$ of glutamine, $1 \%$ antibiotic and antimycotic solution and $10 \%$ fetal bovine serum. 
Cells were incubated in a humidified atmosphere with $5 \% \mathrm{CO}_{2}$ at $37^{\circ} \mathrm{C}$. To carry out the experiments, $3 \times 10^{4}$ cells were seeded in 96-well plates (flat bottom) and allowed to adhere for $24 \mathrm{~h}$ at $37{ }^{\circ} \mathrm{C}$. For cell treatments, these were incubated at $37^{\circ} \mathrm{C}$ for different periods in the presence of the different ION concentrations, or control solutions.

\section{Exposure conditions}

For each assay and each nanoparticle, 10 different concentrations $\left(5,10,25,50,75,100,150,175,200\right.$ and $\left.300 \mu \mathrm{g} \mathrm{ml}^{-1}\right)$, in addition to a negative and a positive control, and three exposure periods $(3,6$ and $24 \mathrm{~h}$ ) were evaluated. Culture medium (specific for each cell line) without ION was used as negative control in all experiments. Triton X-100 (1\%) was used as positive control for all assays.

\section{Interference studies}

To reveal possible interferences between ION and cytotoxicity assays experimental procedure, two sets of experiments were conducted, (1) to analyze the influence of ION presence on absorbance measurements (light absorption interference), and (2) to address possible ION reactivity with assay components. Both sets of experiments were carried out in the absence of cells.

Analysis of influence of iron oxide nanoparticle presence on absorbance measurements (light absorption interference). For the MTT and NRU assays, light absorption interference was analyzed in the presence of dissolving agents (DMSO and fixative solution, for the MTT and NRU assay, respectively) and end-products (formazan dissolved in DMSO and NR dissolved in fixative solution). End-products were obtained by incubating live cells with the MTT and NRU dyes (as described below in the assay sections). ION suspensions were prepared in solvents and end-products at three concentrations (50, 100 and $300 \mu \mathrm{g} \mathrm{ml}^{-1}$ ). Absorbance was measured at $570 \mathrm{~nm}$ and $540 \mathrm{~nm}$, for the MTT and NRU, respectively, using a Cambrex ELx808 microplate reader (KC4; Biotek, Winooski, VT, USA) and compared to blanks (no ION addition).

For the $A B$ assay, ION suspensions were prepared in both resazurin and resorufin. Resorufin was obtained after reduction with formic acid. Since in this assay resazurin reduction occurs in the presence of cell culture media, experiments were carried out using incomplete and complete media of the SHSY5Y and A172 cell lines. ION suspensions (50, 100 and $300 \mu \mathrm{g} \mathrm{ml}^{-1}$ ) were added to the same amount of cell culture media and absorbance was immediately measured at $570 \mathrm{~nm}$ with a reference wavelength of 630 nm (Cambrex ELx808 microplate reader, KC4; Biotek).

Iron oxide nanoparticle reactivity with assay components. This was determined by performing the assays in the absence of cells ( $4 \mathrm{~h}$ of incubation for the MTT and $A B$, and $3 \mathrm{~h}$ for the NRU) (Holder et al., 2012; Kroll et al., 2011). In brief, ION were incubated with assay reagents in the absence of cells and absorbance measured at the end of the incubation period was compared to blank absorbance (no ION addition).

\section{MTT assay}

The MTT assay was performed according to Mosmann (1983). Briefly, after exposure, treatment suspensions were removed, wells were washed with phosphate-buffered saline (PBS) twice, and 100 $\mu$ l of the MTT dye $\left(500 \mu \mathrm{g} \mathrm{ml}^{-1}\right)$ dissolved in serum-free medium were added to each well and the plate was incubated at $37{ }^{\circ} \mathrm{C}$ for $4 \mathrm{~h}$ (protected from light). At the end of this period, the MTT solution was removed and $200 \mu \mathrm{l}$ of DMSO were added. For complete dissolution of purple formazan crystals, the content of each well was quickly resuspended and the plate was kept away from light for an additional period of 5-10 min. Absorbance was measured at $570 \mathrm{~nm}$ using a Cambrex ELx808 microplate reader (KC4; Biotek) and values of ION alone (experiments without cells) were used to correct absorbance obtained in each tested condition.

\section{Neutral red uptake assay}

As previously described by Valdiglesias et al. (2013), at the end of the exposure period ION were removed, wells were washed twice with PBS, and $100 \mu \mathrm{l}$ of NR reagent, prepared in incomplete medium $\left(50 \mu \mathrm{g} \mathrm{ml}^{-1}\right)$, were added to cells and incubated for $3 \mathrm{~h}$ at $37{ }^{\circ} \mathrm{C}$. After removing the NR, $200 \mu \mathrm{l}$ of fixative solution $(50 \%$ ethanol, $1 \%$ acetic acid and $49 \%$ deionized water) were added to extract the dye from cells. Absorbance was measured at $540 \mathrm{~nm}$ using a Cambrex ELx808 microplate reader (KC4; Biotek) and values of ION alone (experiments without cells) were used to correct absorbance obtained in each tested condition.

\section{Alamar blue assay}

The $A B$ assay was carried out as previously described (Borra et al., 2009). At the end of the exposure periods, ION were removed, wells were washed twice with PBS and the AB reagent (resazurin; $100 \mu \mathrm{l})$, prepared in incomplete medium $\left(20 \mu \mathrm{g} \mathrm{ml}^{-1}\right)$, was added to the cells, and then incubated for $4 \mathrm{~h}$ at $37^{\circ} \mathrm{C}$. Spectrophotometric absorbance was taken at $570 \mathrm{~nm}$ with a reference wavelength of $630 \mathrm{~nm}$, using a Cambrex ELx808 microplate reader (KC4; Biotek). Absorbance values of ION alone (experiments without cells) were used to correct absorbance obtained in each tested condition.

\section{Statistical analysis}

Statistical analyses were performed using SPSS for Windows statistical package (version 22.0). Non-parametric tests (Mann-Whitney U-test [differences among groups] and Spearman's correlation [associations between two variables]) were used for the statistical analysis of these data. A minimum of three independent experiments (in viability assays, three replicates were analyzed in each experiment) were performed for each experimental condition tested. Experimental data were expressed as mean \pm standard error and a $P$-value of 0.05 was considered significant.

\section{Results}

\section{Nanoparticle characterization}

Table 1 summarizes the main physicochemical properties of ION employed in this study, such as primary size, hydrodynamic size in water and cell culture media (complete and serum-free), surface characteristics and electrokinetic potential (indicative of colloidal stability). TEM microscopy revealed, in both cases, a spherical morphology and in the case of S-ION, a core-shell structure with a silica coating was clearly seen (Fig. 1).

Surface chemistry analysis revealed that only a small fraction of the ION surface presents iron (less than 7\% for OA-ION and 2\% for S-ION). S-ION also presented carbon and nitrogen in their surface, 


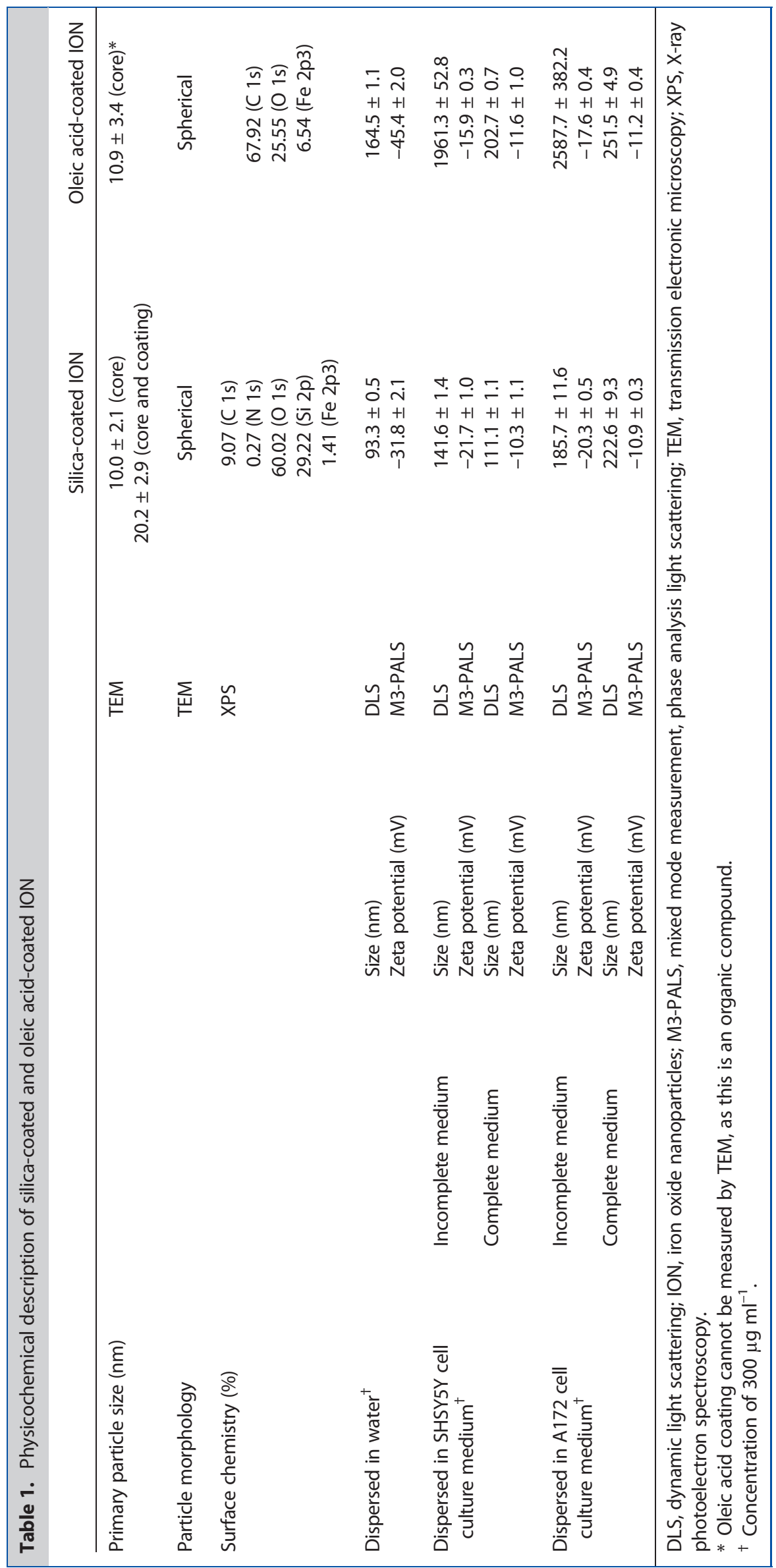



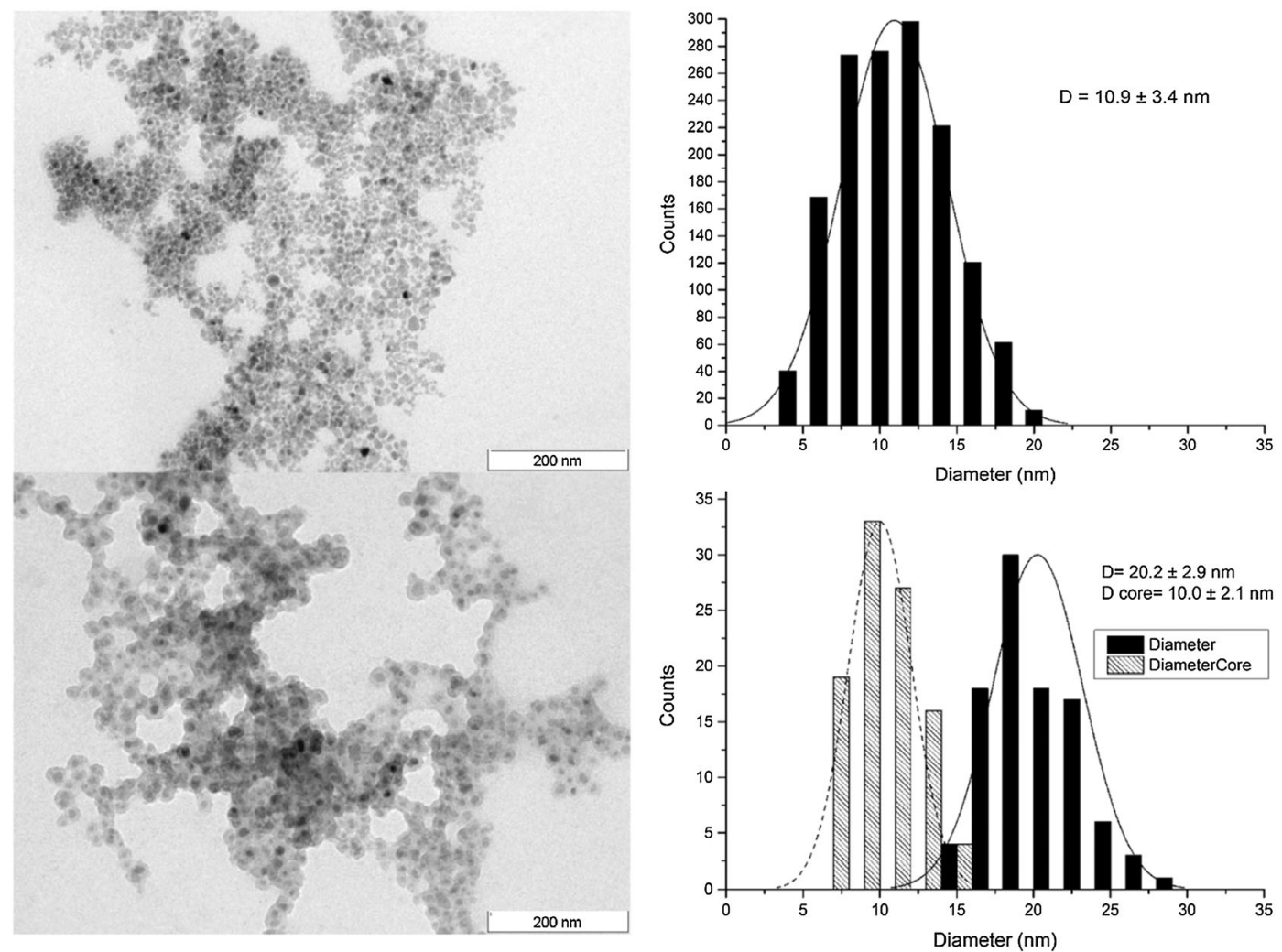

Figure 1. Transmission electron microscopy images and corresponding diameter histograms of the nanoparticles used in this work. (a) Oleic acid-iron oxide nanoparticles and (b) silica-iron oxide nanoparticles showing both the size of the magnetic core and the total size, including the silica layer.

possibly resultant from the synthesis process (reverse microemulsion using cyclohexane, ammonium hydroxide and tetraethyl orthosilicate). Hydrodynamic size measurements showed that ION, both S-ION and OA-ION, maintain their nanoparticle size when dispersed in water and complete medium but OA-ION agglomerate notably when dispersed in incomplete medium and exhibit a size in the micron range $(1961.3 \mathrm{~nm}$ and $2587.7 \mathrm{~nm}$ in SHSY5Y and A172 incomplete media, respectively). All dispersions showed a negative charge, but values indicating stable colloidal dispersions (lower than $-30 \mathrm{mV}$ or higher than $30 \mathrm{mV}$ ) were only observed for ION in water.

\section{Nanoparticle interference with in vitro cytotoxicity assays}

Absorption spectra of ION studied herein dispersed in water showed notable absorption levels at wavelengths used in cytotoxicity assays, indicating that these nanoparticles may interfere with the spectrophotometric read-out (data not shown). In this context, different tests were carried out to assess the possible interference of ION with the cytotoxicity assays to be used.

As mentioned above, interference with light absorption was analyzed in the presence of both dissolving agents and reaction products for the NRU and MTT assays (Fig. 2). Results show that the presence of ION (both silica- and oleic acid-coated) is responsible for a significant increase in absorbance in all cases, with the exception of S-ION, in the presence of solubilized formazan. In general, it seems that for the NRU and MTT assays, interference issues are more relevant whenever the assay reaction does not occur (ION dispersed in DMSO or fixative solution), what means that absorbance is particularly overestimated in cases of low viability. In addition, interferences were more pronounced for OA-ION.

Regarding the $A B$ assay, interferences were tested in the presence of SHSY5Y and A172 serum-free cell culture media (since
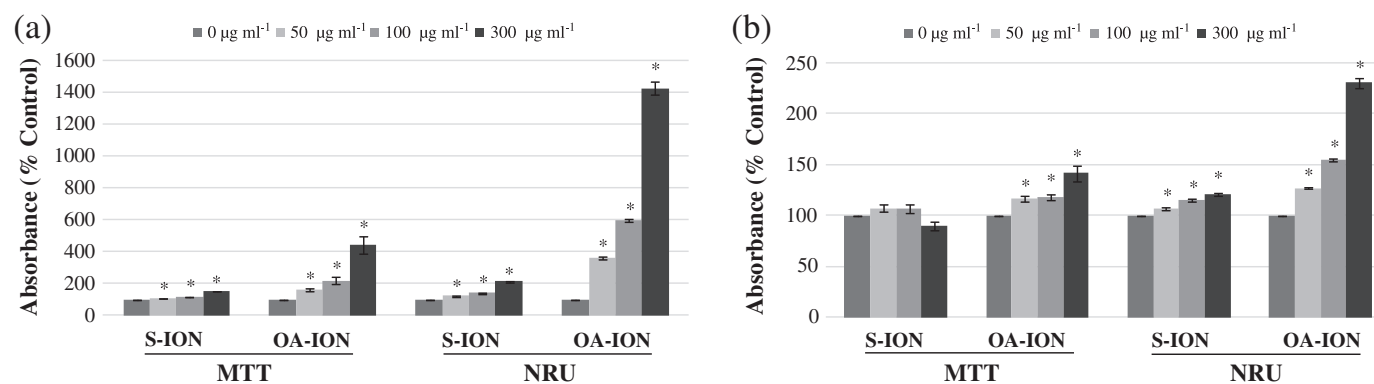

Figure 2. Interference of ION with the MTT and NRU assays. Results of interference experiments with dissolving agents (a) and reaction products (b). ${ }^{*} P<0.05$, significantly different from the control. MTT, 3-(4,5-dimethylthiazol-2-yl)-2,5-diphenyltetrazolium bromide (assay); NRU, neutral red uptake (assay); OA-ION, oleic acid-iron oxide nanoparticles; S-ION, silica-iron oxide nanoparticles. 

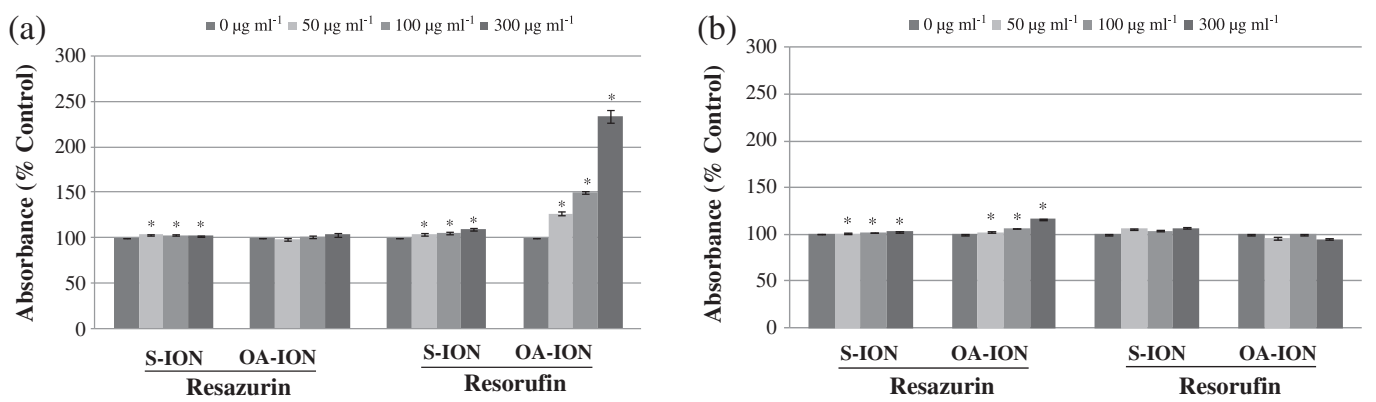

Figure 3. Interference of ION with the alamar blue assay. Results of interference experiments with reactant (resazurin) and reaction product (resorufin) using: (a) SHSY5Y serum-free cell culture media and (b) A172 serum-free cell culture media. ${ }^{*} P<0.05$, significantly different from the control. OA-ION, oleic acid-iron oxide nanoparticles; S-ION, silica-iron oxide nanoparticles.

in this assay, resazurin prepared in incomplete medium is not removed from the wells before colorimetric analysis, as it was done with the MTT or NR in the previously detailed cytotoxicity assays). Results obtained are presented in Fig. 3. As evidenced in this figure, ION were able to interfere significantly with light absorbance in both media. For SHSY5Y cell culture media, interferences were limited to situations of low viability (in which the $A B$ is not reduced by cells and, therefore, remains as resazurin at the time of absorbance measurements). Although the presence of ION nanoparticles significantly altered these readings, the increase observed was below $20 \%$ even for the highest concentration $\left(300 \mu \mathrm{g} \mathrm{ml}^{-1}\right.$ ). Different results were obtained when analyzing ION interference with the $A B$ assay in the presence of $A 172$ cell culture media. In this case, differences were much more pronounced when readings were carried out in the presence of resorufin, indicating that interferences are particularly relevant whenever there is high cell viability.

The second set of experiments carried out to understand ION interference with cytotoxicity assays intended to analyze the reactivity of ION with dyes by performing the whole assay protocol with the ION in the absence of cells. Experiments were performed using cell culture media of the two cell lines under study but, as results were found to be similar, only data concerning A172 cell culture medium are presented (Fig. 4). Results obtained in the presence of OA-ION showed a significant dose-dependent increase of formazan production (incomplete medium: $r=0.557, P<0.001$; complete medium: $r=0.649, P<0.001$ ) and NRU (incomplete medium: $r=0.654, P<0.001$; complete medium: $r=0.680, P<0.001$ ). $\mathrm{S}-\mathrm{ION}$ were also able to mimic the NRU in incomplete medium $(r=0.371, P<0.001)$. In what concerns the AB assay, no significant alterations in absorbance were observed (Fig. 3c).

\section{In vitro cytotoxicity}

After cell exposure to different concentrations of S-ION and OA-ION, viability was assessed by employing the MTT, NRU and $A B$ assays. Results obtained for the SHSY5Y cell line are presented in Figs. 5 and 6, respectively. Exposure to S-ION in incomplete medium induced a significant decrease in cell viability assessed by the MTT ( 3 and $24 \mathrm{~h}$ ) and NRU assays ( 6 and $24 \mathrm{~h}$ ) but not by the AB assay. In opposition, exposure to S-ION in complete medium was responsible for a significant decrease in viability only after $24 \mathrm{~h}$ of exposure (more evident in the NRU and AB assays). In what concerns SHSY5Y exposure to OA-ION, there was no clear decrease in cell viability when exposure was carried out in complete medium. Nevertheless, in incomplete medium, the highest concentrations

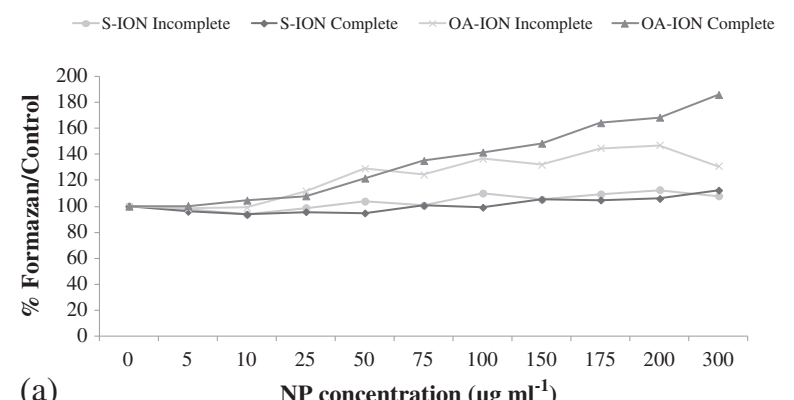

(a)

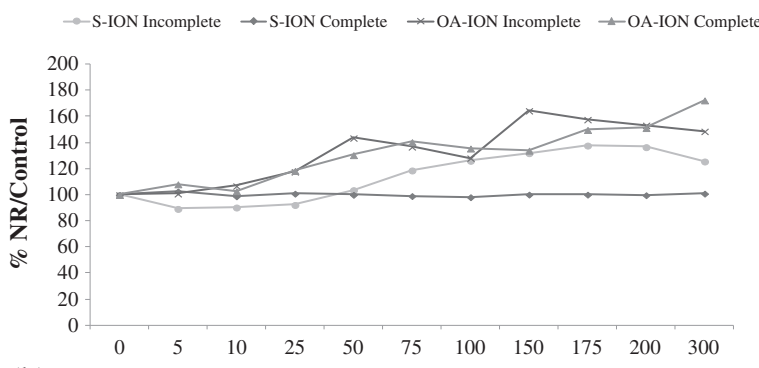

(b)

NP concentration $\left(\mu \mathrm{g} \mathrm{ml}^{-1}\right)$

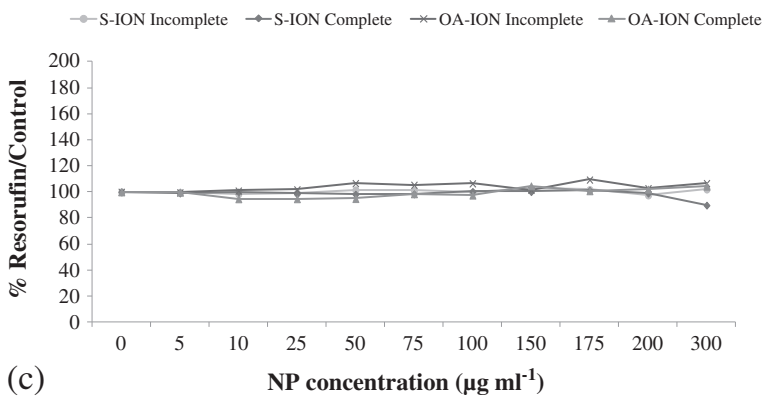

Figure 4. Reactivity of ION in the absence of cells with the MTT (a), alamar blue (b) and NR uptake (c) assay reactants in A172 cell culture medium. NP, nanoparticle; NR, neutral red; OA-ION, oleic acid-iron oxide nanoparticles; S-ION, silica-iron oxide nanoparticles.

employed (200 and $300 \mu \mathrm{g} \mathrm{ml}^{-1}$ ) reduced the viability of SHSY5Y cells significantly in the case of the MTT and NRU assays (Fig. 6).

Figures 7 and 8 present A172 viability after exposure to S-ION and OA-ION, in incomplete and complete media. In accordance to what was observed in the SHSY5Y cell line, after exposure to $\mathrm{S}-\mathrm{ION}$ in incomplete medium, decreases in cell viability of A172 was also observed at all studied times of exposure assessed by the MTT and NRU assays. Moreover, the decline in viability observed in this cell line was more pronounced than the one 
SHSY5Y viability after exposure to S-ION

(a)

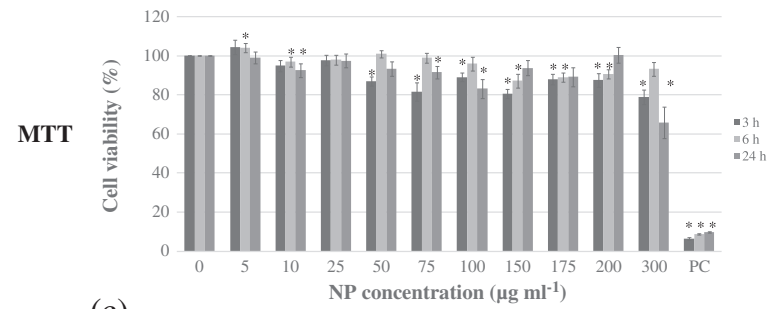

(c)

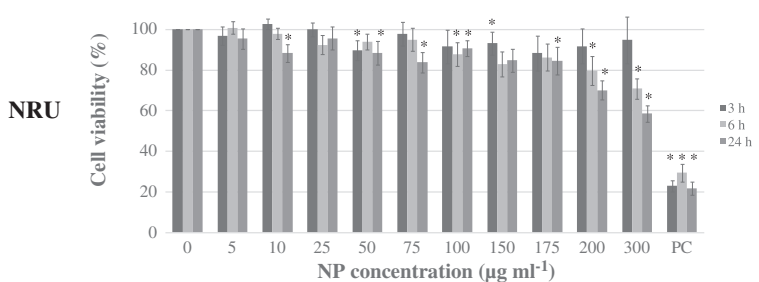

(e)

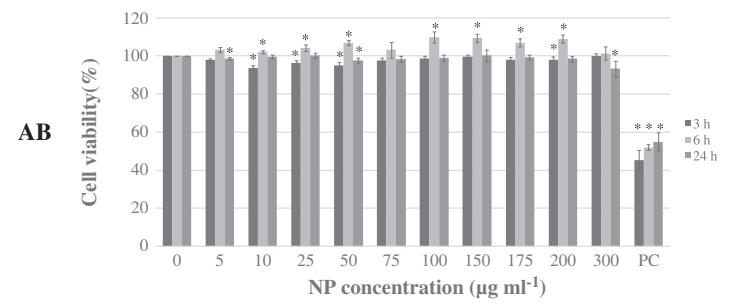

Complete medium

(b)

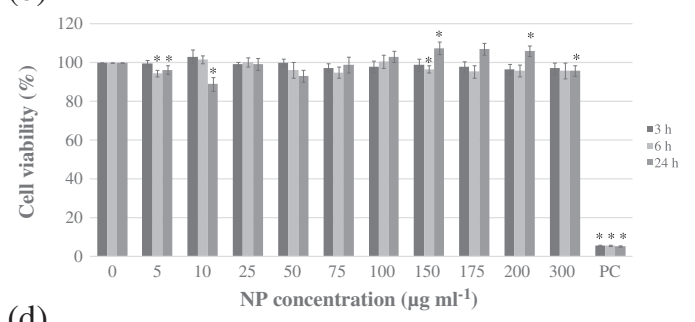

(d)

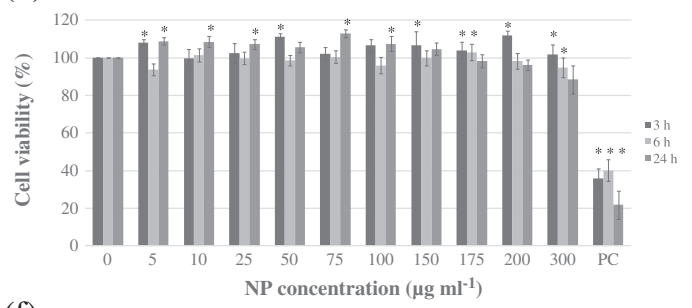

(f)

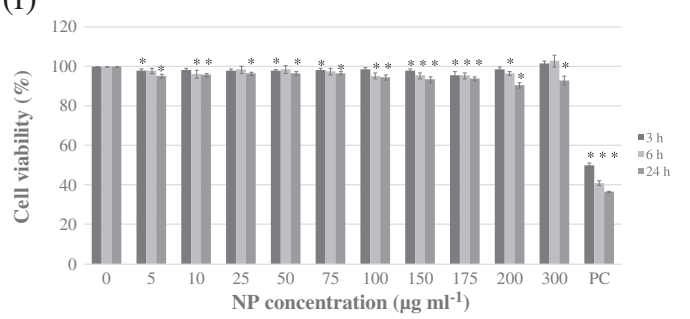

Figure 5. Cell viability of the SHSY5Y cell line after exposure to silica-iron oxide NP. Viability was assessed by: MTT assay in incomplete (a) and complete media (b); neutral red uptake assay in incomplete (c) and complete media (d); and alamar blue assay in incomplete (e) and complete media (f). Bars represent standard error of the mean. Values were normalized considering negative control as $100 \%$. ${ }^{*} P<0.05$, significant difference with regard to the corresponding negative control. NP, nanoparticle; PC, positive control.

observed in SHSY5Y cells: after $24 \mathrm{~h}$ of exposure to $300 \mu \mathrm{g} \mathrm{ml}^{-1}$ of S-ION in incomplete medium, A172 cell viability was found to be lower than $40 \%$ in opposition to $58 \%$ of SHSY5Y cell viability identified in the same conditions. Moreover, exposure to S-ION in incomplete medium for $24 \mathrm{~h}$ was also able to decrease cell viability significantly after analysis by the $A B$ assay (Fig. 7e). In complete medium, exposure to S-ION was responsible for a reduction in viability after $3 \mathrm{~h}$ (MTT assay), $6 \mathrm{~h}$ (MTT and NRU assays) and $24 \mathrm{~h}$ (MTT, NRU and AB assays). Percentages of cell viability observed after exposure to S-ION in complete medium were consistently higher than those observed after exposure to the same ION in incomplete medium.

Regarding the effect of OA-ION in A172 viability, it was observed a significant decrease after $3 \mathrm{~h}$ (MTT assay) and $24 \mathrm{~h}$ (MTT and AB assays) of exposure to these ION in incomplete medium. The NRU results showed significantly decreased levels of live cells only after exposure to $300 \mu \mathrm{g} \mathrm{ml}^{-1}$ of OA-ION when compared with the corresponding control, at all periods of exposure studied. OA-ION dispersed in complete medium were also responsible for a significant reduction in viability after $3 \mathrm{~h}$ (MTT and NRU assays), $6 \mathrm{~h}$ (NRU assay) and $24 \mathrm{~h}$ (AB assay) of exposure.

\section{Discussion}

Throughout the years it has become clear that physicochemical characterization of test materials is essential in toxicity screening (Sayes and Warheit, 2009). In addition to primary characterization, in the current study nanoparticles were also characterized under biologically relevant conditions, as these are the most significant for in vitro nanotoxicology (Warheit, 2008). ION dispersed in cell culture media showed a larger size and lower stability than those dispersed in water (both S-ION and OA-ION in either complete or incomplete media). Previous studies have shown that this increase in size is due to the formation of agglomerates at physiological $\mathrm{pH}$ and electrolyte concentration (Bihari et al., 2008). Even in water, these particles present a much larger diameter by DLS than the one determined by the TEM, indicating that these particles are not particularly stable. In the case of OA-ION, this can be due to a partial desorption of the bilayer of oleic acid when the particles are diluted in water from the stock solution, while for S-ION it could be noticed in the TEM images that some particles appear joined together by the silica layer resulting in a much greater hydrodynamic diameter. Results obtained here revealed the importance of serum presence, particularly for OA-ION. The influence of a dynamic corona has been increasingly studied as it became evident that the adsorption of proteins present in a biological environment is able to modify nanomaterial surfaces and their biological impacts (Lynch and Dawson, 2008). Different studies have shown the importance of serum as a dispersant (leading to improved particle dispersion and stability over time) and reported that, at the same time that serum is responsible for size increase due to the formation of a corona around particles, it also prevents the magnetic nanoparticles from agglomerating by providing steric hindrance (Wiogo et al., 2011). DLS results obtained for OA-ION showed that for these nanoparticles, serum presence is essential to obtain good particle dispersion, in both SHSY5Y and A172 incomplete media, 
SHSY5Y viability after exposure to OA-ION

(a)

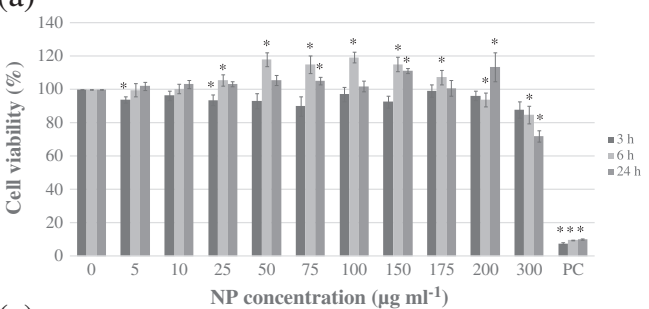

(c)

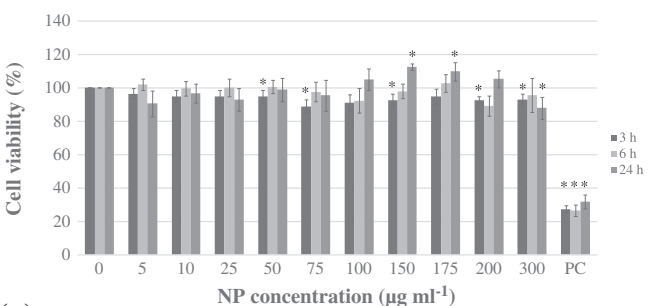

(e)

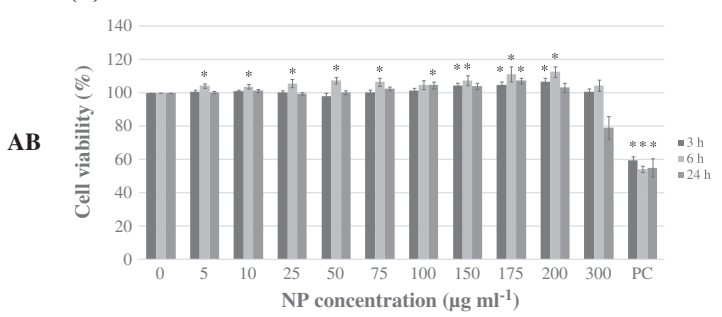

(b)

Complete medium

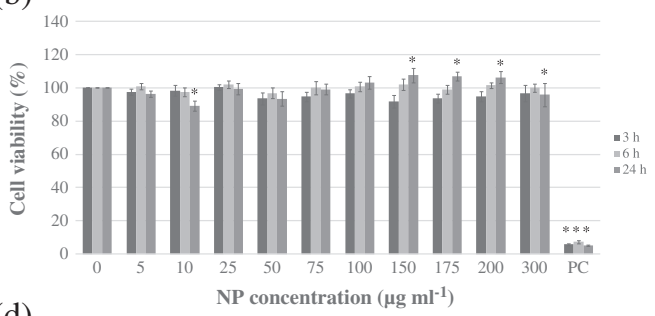

(d)

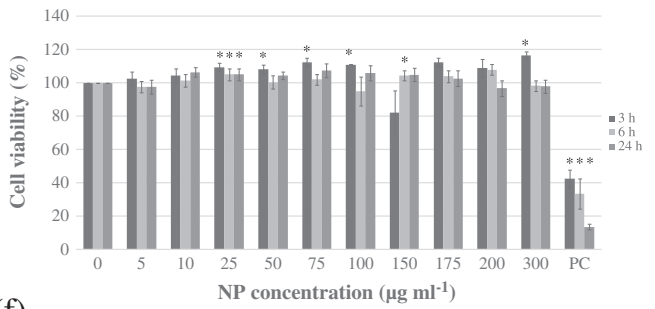

(f)

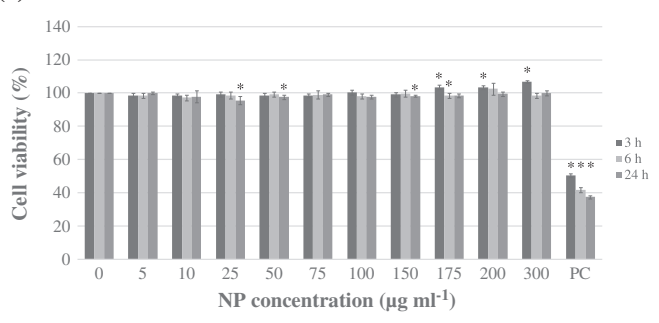

Figure 6. Cell viability of the SHSY5Y cell line after exposure to oleic acid-iron oxide NP. Viability was assessed by: MTT assay in incomplete (a) and complete media (b); neutral red uptake assay in incomplete (c) and complete media (d); and alamar blue assay in incomplete (e) and complete media ( $\mathrm{f}$ ). Bars represent standard error of the mean. Values were normalized considering negative control as $100 \%$. ${ }^{*}<0.05$, significant difference with regard to the corresponding negative control. NP, nanoparticle; PC, positive control.

OA-ION presented significant agglomeration, as particle average size was 10 times higher than the one observed in complete media. On the other hand, S-ION size was not so influenced by serum presence and presented similar values in both complete and incomplete media. Coating stability is the probable cause for these differences between S-ION and OA-ION, as strongly covalently bound silica shells do not present the possibility of desorption as oleic acid coating (Wu et al., 2008).

One of the most recently discussed issues of nanotoxicology is the appropriateness of classical in vitro cytotoxicity assays to assess cell viability. Different authors have shown that results obtained may not be reliable due to nanoparticle interference with assay components (Love et al., 2012; Monteiro-Riviere et al., 2009; Stone et al., 2009), thus cell death indexes may be either underestimated (Wörle-Knirsch et al., 2006) or overestimated (Laaksonen et al., 2007). Possible causes of interference include nanoparticle interference with light absorption (Kroll et al., 2009), chemical reactions between nanoparticles and reactants (Monteiro-Riviere et al., 2009), and dye adsorption on nanoparticle surface (Holder et al., 2012). Different strategies have been used to obviate interference between nanoparticles and assay readings: use of cells treated with the same concentrations of nanoparticles but without assay reagents as blanks (Hoskins et al., 2012), plate centrifugation before absorbance measurements (Han et al., 2011), use of cell-free systems (wells without cells but with all assay reagents) as blanks (Belyanskaya et al., 2007), or cell wash after incubation period to remove the remaining nanoparticles (Hoskins et al., 2012). The evaluation of possible interactions between ION analyzed in this study and cytotoxicity assays showed that interference in results could not be completely ruled out with these nanoparticles. S-ION and OA-ION appear to interfere both in optical measurement and assay reaction (by reacting with assay components and producing measurable end-products). To avoid these interferences, in the protocols we included washing steps after treatments with the ION and before dye incubation, and a cell-free system to correct for ION-dye reactivity. Nevertheless, it is difficult to ensure that all interferences were in fact controlled as some ION are internalized by cells and probably interfere with optical measurements (for the MTT and NRU assays, as no reactivity in absence of cells was detected in the AB assay; Fig. $3 c$ ). According to this evidence, we can conclude that for the MTT the cell viability may be slightly overestimated, particularly in the case of A172 exposure to S-ION (case of lowest viability). The results obtained after exposure to OA-ION can also be overestimated, as in the presence of formazan these ION are responsible for a significant increase in absorbance. For the $A B$ assay, the results indicate that viability of the $A 172$ cell line can be also overestimated. In fact, this possible interference leading to viability overestimation may explain the increase in viability (above 100\%) observed in certain conditions (e.g., in the A172 cell line using the NRU assay in complete medium for $24 \mathrm{~h}$ ). Nevertheless, previous studies have described increases in cell proliferation in the presence of nanoparticles. For instance, silver nanoparticles accelerated proliferation of HepG2 cells at low doses, meanwhile they exhibited significant cytotoxicity at higher doses (Kawata et al., 2009), and Ferucarbotran (an ionic superparamagnetic ION) increased growth of human mesenchymal stem cells 
(a)

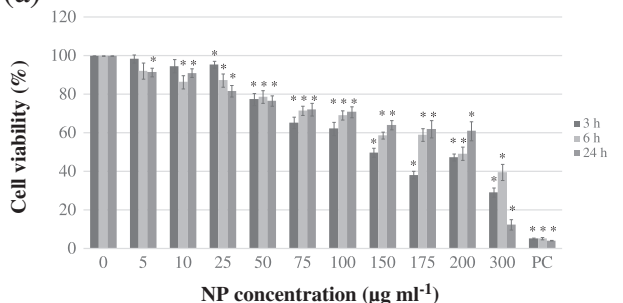

(c)

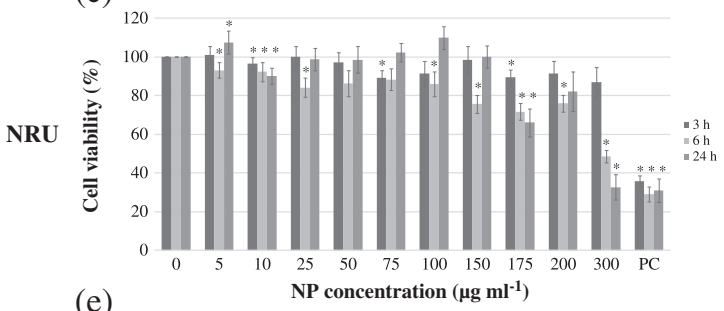

(e)

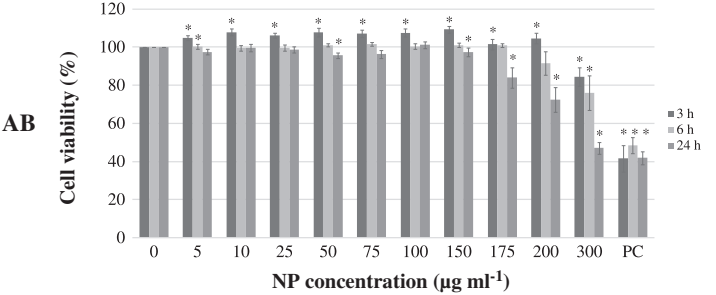

A172 viability after exposure to S-ION
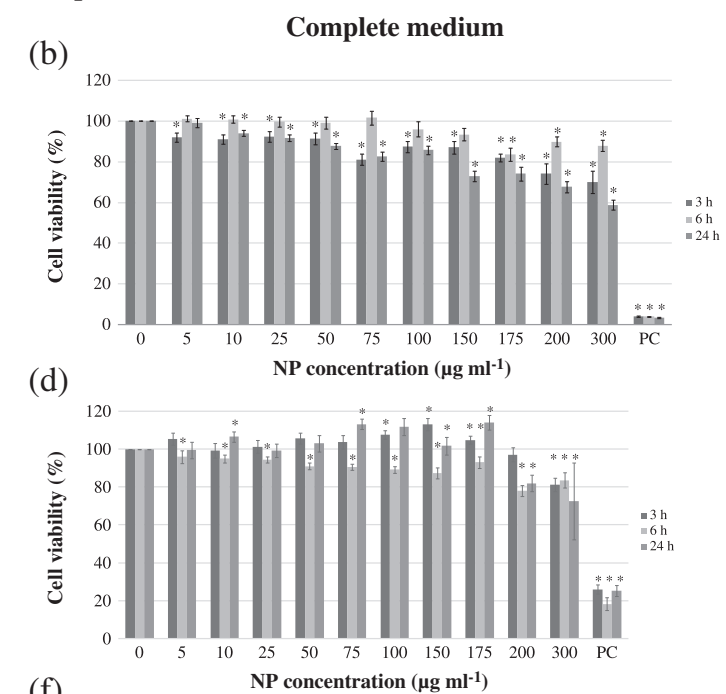

(f)

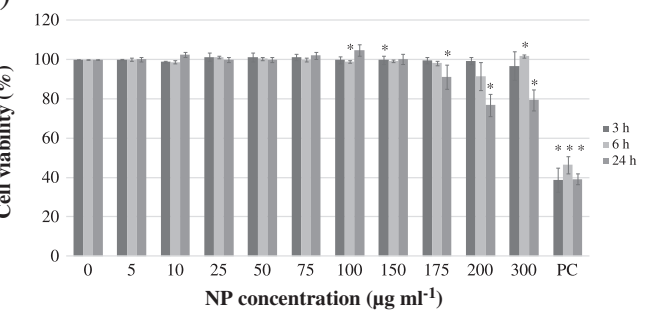

Figure 7. Cell viability of the A172 cell line after exposure to silica-iron oxide NP. Viability was assessed by: MTT assay in incomplete (a) and complete media (b); neutral red uptake assay in incomplete (c) and complete media (d); and alamar blue assay in incomplete (e) and complete media ( $f$ ). Bars represent standard error of the mean. Values were normalized considering negative control as $100 \%$. ${ }^{*} P<0.05$, significant difference with regard to the corresponding negative control. NP, nanoparticle; PC, positive control.

(Huang et al., 2009). In the current study, increases in viability were only observed in SHSY5Y cells and in a variety of situations, not restricted to specific times of exposure or concentration ranges. Nevertheless, cell cycle experiments carried out in the same conditions (same cell lines, cell culture conditions, ION, exposure times and doses) showed alterations in the regular cell proliferation only for the highest concentrations and exposure time (data not shown). Taken together, these results suggest that the increase in viability may be more likely due to interference of the ION with the methodologies of the assays than to the actual induction of cell proliferation.

There are several in vitro studies that have demonstrated little or no toxicity of ION, which led to the suggestion that these are biocompatible nanomaterials (Boyer et al., 2010). Earlier studies on neurotoxicity of ION revealed a decrease in viability of mouse neuroblastoma cells after exposure to bare ION $\left(200 \mu \mathrm{g} \mathrm{ml}^{-1}\right)$, assessed by the MTT assay ( Jeng and Swanson, 2006). In addition, Au et al. (2007) and Pisanic-Il et al. (2007) described significant decreases in cell viability of astrocytes and pheochromocytoma neuronal cell lines, respectively, after exposure to ION. The MTT and AB assays provide information on mitochondrial activity (Hillegass et al., 2010), while the NRU assay evaluates lysosomal integrity (Repetto et al., 2008). More recently, it has been described that a reduction of the $A B$ can also occur in subcellular components and not only in mitochondria, which means that $A B$ reduction is related to cellular metabolism impairment and is not entirely due to interruption of electron transport and mitochondrial dysfunction (Rampersad, 2012). Previous studies stated that ION are stored in lysosomes where they decompose to free iron (Laskar et al., 2012; Laurent et al., 2012). Free iron ions can affect mitochondria and/or increase radical concentration. In addition, ION can also directly damage mitochondria by causing morphological alterations or decrease in mitochondrial membrane potential (Frohlich, 2013). Our results showed the lowest viability detected by the MTT assay, in comparison with the remaining assays, suggesting that mitochondria is particularly sensitive to the ION studied herein in accordance to what has been stated in previous studies (Jeng and Swanson, 2006).

The results obtained suggest that OA-ION present a lower cytotoxicity than S-ION. The composition of ION coating may be based on the different cytotoxic effects observed, as it has been extensively reported that external modification can significantly affect the chemical reactivity of a material and thereby its potential toxic effects (Hong et al., 2011). On the other hand, one cannot overlook the differences observed in size when using incomplete medium. In these conditions, differences observed in toxicity between the two types of nanoparticles are likely related to dispersion, as OA-ION were found to be prone to agglomeration in serum-free media. As improved dispersion can be responsible for an increase in particle reactivity (Stone et al., 2009), agglomeration state and protein corona may actually have implications on the toxicity of a particle due to alteration of the particle dynamics and consequent modification of patterns of cell-ION interaction. An additional factor that must be pointed out is the presence of carbon and nitrogen on the S-ION surface, which indicates that residues resulting from the synthesis process are still present in 
A172 viability after exposure to OA-ION

(a)

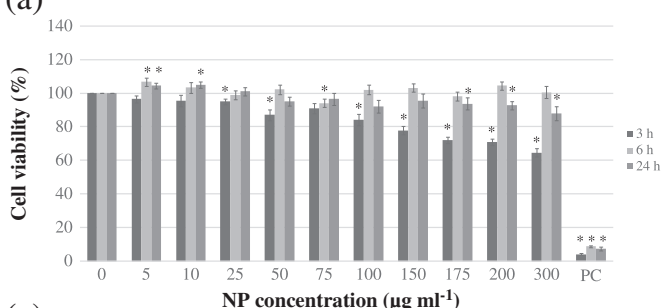

(c)

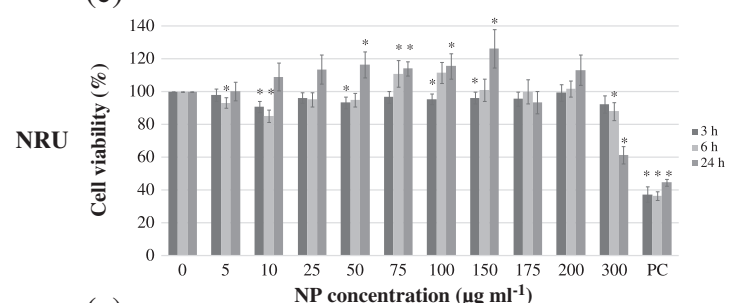

(e)

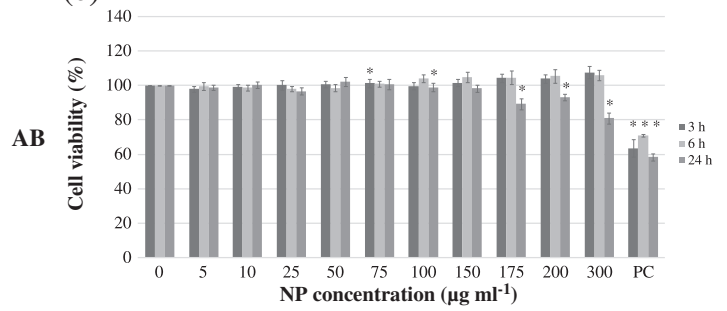

(b)

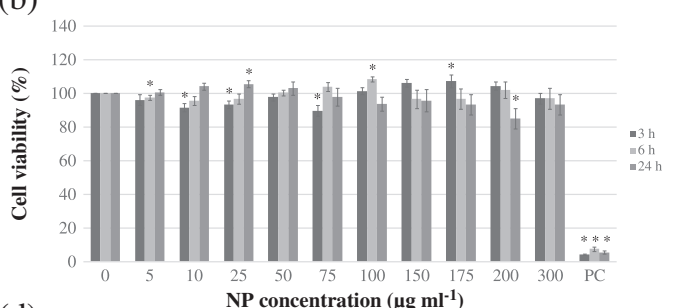

(d)

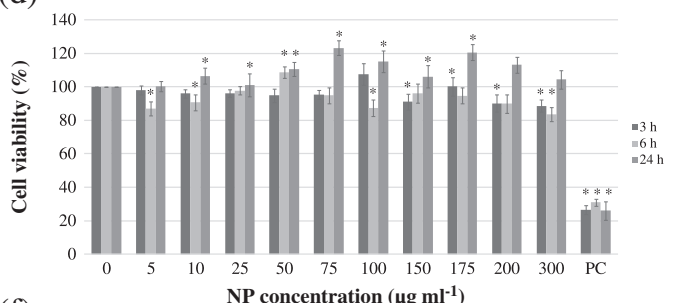

(f)

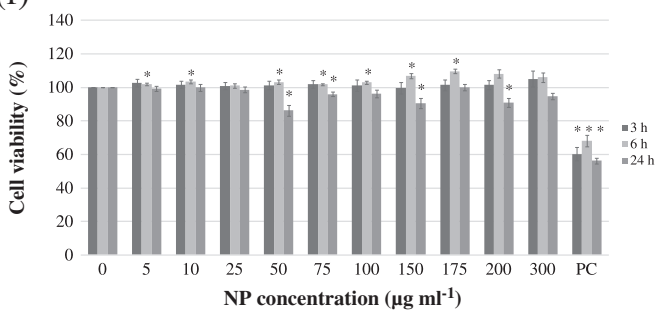

Figure 8. Cell viability of the A172 cell line after exposure to oleic acid-iron oxide NP. Viability was assessed by: MTT assay in incomplete (a) and complete media (b); neutral red uptake assay in incomplete (c) and complete media (d); and alamar blue assay in incomplete (e) and complete media (f). Bars represent standard error of the mean. Values were normalized considering negative control as $100 \% .{ }^{*} P<0.05$, significant difference with regard to the corresponding negative control. NP, nanoparticle; PC, positive control.

nanoparticles. If the presence of these residues in nanoparticles influences toxicity is unknown; however, this is a serial confounder that must be addressed in further studies (Crist et al., 2013).

The presence of serum in cell culture media is an important factor to consider as it has been reported that its presence may result in different biological effects (Geys et al., 2010). Proteins or other macromolecules present in media immediately bind to nanoparticles creating a protein corona. It has been shown that serum presence may mask the reactive surface of nanoparticles preventing a cell-nanoparticle interaction, lower cellular uptake and neutralize the increased sensitivity of serum-deprived cells (Frohlich, 2013). Our results confirm this serum-protective effect as lower viability was observed in incomplete medium, as compared with complete medium, for both ION and cell lines studied.

Two different cell models were used in this study to understand the potential neurotoxic effects of S-ION and OA-ION. Previous studies using both neuroblastoma and glioblastoma cell lines to address metal oxide nanoparticle toxicity have shown that the SHSY5Y cell line is usually more sensitive than the glioblastoma cell lines (Chen et al., 2008). On the other hand, other studies on chemical toxicity suggest that glial cells may be more sensitive than neural cells (Stockmann-Juvala et al., 2006), as it was observed in this study. A possible bias for this comparison is the cell cycle state at which cells were at the time of treatment. In this study, cells were seeded to reach confluence at exposure in agreement with previously published work (Kroll et al., 2011, 2012). However, cells in diverse states of the cell cycle express different biomolecules and respond differently to exogenous stimuli (Bregoli et al., 2013).

\section{Conclusion}

ION are undoubtedly promising nanomaterials with different and important applications in the biomedical field. As new nanoparticles are currently produced and introduced to the market, it is of paramount importance to evaluate their potential neurotoxicity, as the self-regenerative ability of neurons is limited.

In vitro systems used herein were limited to single cell types and therefore were not able to replicate the intricate interactions that occur in vivo. Nevertheless, information obtained in in vitro studies can be useful to predict new targets to define better strategies for in vivo evaluations (de Jesus and Kapila, 2014).

Results obtained in this work show the importance of studying nanoparticle interference in currently used cytotoxicity assays, to obtain reliable results to improve knowledge on biological effects of ION. Despite these possible interferences, classical cytotoxicity assays remain standard procedure to screen nanoparticle biological effects. Cytotoxicity screening assays presented herein allowed the identification of adverse cellular effects on the neuroblastoma and glioblastoma cell lines in certain conditions and, consequently, further studies to explore protein corona formation and the underlying molecular mechanisms of toxicity are now matter of investigation.

\section{Acknowledgments}

This work was funded by Xunta de Galicia (EM 2012/079) and by TD1204 MODENA COST Action. G.K. was supported by a fellowship from the University of A Coruña. 


\section{Conflict of Interest}

The authors did not report any conflict of interest.

\section{References}

Au C, Mutkus L, Dobson A, Riffle J, Lalli J, Aschner M. 2007. Effects of nanoparticles on the adhesion and cell viability on astrocytes. Biol. Trace Elem. Res. 120: 248-256.

Babič M, Horák D, Jendelová P, Glogarová K, Herynek V, Trchová M, Likavčanová K, Lesný P, Pollert E, Hájek M, Syková E. 2009. Poly $(N, N-$ dimethylacrylamide)-coated maghemite nanoparticles for stem cell labeling. Bioconjug. Chem. 20(2): 283-294.

Belyanskaya L, Manser P, Spohn P, Bruinink A, Wick P. 2007. The reliability and limits of the MTT reduction assay for carbon nanotubes-cell interaction. Carbon 45(13): 2643-2648.

Berridge MV, Tan AS, McCoy KD, Wang R. 1996. The biochemical and cellular basis of cell proliferation assays that use tetrazolium salts. Biochemica 4: 14-19.

Bihari P, Vippola M, Schultes S, Praetner M, Khandoga AG, Reichel CA, Coester C, Tuomi T, Rehberg M, Krombach F. 2008. Optimized dispersion of nanoparticles for biological in vitro and in vivo studies. Part. Fibre Toxicol. 5: 14.

Borra RC, Lotufo MA, Gagioti SM, Barros FM, Andrade PM. 2009. A simple method to measure cell viability in proliferation and cytotoxicity assays. Braz. Oral Res. 23: 255-262.

Boyer C, Whittaker MR, Bulmus V, Liu J, Davis TP. 2010. The design and utility of polymer-stabilized iron-oxide nanoparticles for nanomedicine applications. NPG Asia Mater. 2: 23-30.

Bregoli L, Benetti F, Venturini M, Sabbioni E. 2013. ECSIN's methodological approach for hazard evaluation of engineered nanomaterials. J. Phys. Conf. Ser. 429: 012017.

Chen Z, Yin J-J, Zhou Y-T, Zhang Y, Song L, Song M, Hu S, Gu N. 2012. Dual enzyme-like activities of iron oxide nanoparticles and their implication for diminishing cytotoxicity. ACS Nano 6(5): 4001-4012.

Chen J, Zhu J, Cho H-H, Cui K, Li F, Zhou X, Rogers JT, Wong STC, Huang X. 2008. Differential cytotoxicity of metal oxide nanoparticles. J. Exp. Nanosci. 3(4): 321-328.

Clift MJ, Gehr P, Rothen-Rutishauser B. 2011. Nanotoxicology: a perspective and discussion of whether or not in vitro testing is a valid alternative. Arch. Toxicol. 85: 723-731.

Crist RM, Grossman JH, Patri AK, Stern ST, Dobrovolskaia MA, Adiseshaiah PP, Clogston JD, McNeil SE. 2013. Common pitfalls in nanotechnology: lessons learned from NCl's Nanotechnology Characterization Laboratory. Integr. Biol. (Camb.) 5: 66-73.

de Jesus M, Kapila Y. 2014. Cellular mechanisms in nanomaterial internalization, intracellular trafficking, and toxicity. In Nanotoxicology, Durán N Guterres SS, Alves OL (eds). Springer: New York; 201-227.

Domey J, Haslauer L, Grau I, Strobel C, Kettering M, Hilger I. 2014. Probing the Cytotoxicity of Nanoparticles: Experimental Pitfalls and Artifacts. Springer: Berlin; 1-14.

Dunning MD, Lakatos A, Loizou L, Kettunen M, ffrench-Constant C, Brindle KM, Franklin RJM. 2004. Superparamagnetic iron oxide-labeled Schwann cells and olfactory ensheathing cells can be traced in vivo by magnetic resonance imaging and retain functional properties after transplantation into the CNS. J. Neurosci. 24(44): 9799-9810.

Frohlich E 2013. Cellular targets and mechanisms in the cytotoxic action of non-biodegradable engineered nanoparticles. Curr. Drug Metab. 14(9): 976-988.

Geys J, Nemery B, Hoet PHM. 2010. Assay conditions can influence the outcome of cytotoxicity tests of nanomaterials: Better assay characterization is needed to compare studies. Toxicol. In Vitro 24(2): 620-629.

Han X, Gelein R, Corson N, Wade-Mercer P, Jiang J, Biswas P, Finkelstein JN, Elder A, Oberdörster G. 2011. Validation of an LDH assay for assessing nanoparticle toxicity. Toxicology 287(1-3): 99-104.

Hillegass JM, Shukla A, Lathrop SA, MacPherson MB, Fukagawa NK, Mossman BT. 2010. Assessing nanotoxicity in cells in vitro. Wiley Interdiscip. Rev. Nanomed. Nanobiotechnol. 2(3): 219-231.

Holder AL, Goth-Goldstein R, Lucas D, Koshland CP. 2012. Particleinduced artifacts in the MTT and LDH viability assays. Chem. Res. Toxicol. 25(9): 1885-1892.

Hong SC, Lee JH, Lee J, Kim HY, Park JY, Cho J, Lee J, Han DW. 2011. Subtle cytotoxicity and genotoxicity differences in superparamagnetic iron oxide nanoparticles coated with various functional groups. Int. J. Nanomedicine 6: 3219-3231.
Hoskins C, Wang L, Cheng WP, Cuschieri A. 2012. Dilemmas in the reliable estimation of the in-vitro cell viability in magnetic nanoparticle engineering: which tests and what protocols? Nanoscale Res. Lett. 7: 77.

Huang D-M, Hsiao J-K, Chen Y-C, Chien L-Y, Yao M, Chen Y-K, Ko B-S, Hsu S-C, Tai L-A, Cheng H-Y, Wang S-W, Yang C-S, Chen Y-C. 2009. The promotion of human mesenchymal stem cell proliferation by superparamagnetic iron oxide nanoparticles. Biomaterials 30(22): 3645-3651.

Jeng HA, Swanson J. 2006. Toxicity of metal oxide nanoparticles in mammalian cells. J. Environ. Sci. Health A Tox. Hazard. Subst. Environ. Eng. 41(12): 2699-2711.

Kawata K, Osawa M, Okabe S. 2009. In vitro toxicity of silver nanoparticles at noncytotoxic doses to HepG2 human hepatoma cells. Environ. Sci. Technol. 43(15): 6046-6051.

Kenzaoui BH, Bernasconi CC, Hofmann H, Juillerat-Jeanneret L. 2012. Evaluation of uptake and transport of ultrasmall superparamagnetic iron oxide nanoparticles by human brain-derived endothelial cells. Nanomedicine 7: 39-53.

Kroll A, Dierker C, Rommel C, Hahn D, Wohlleben W, Schulze-lsfort C, Gobbert C, Voetz M, Hardinghaus F, Schnekenburger J. 2011. Cytotoxicity screening of 23 engineered nanomaterials using a test matrix of ten cell lines and three different assays. Part. Fibre Toxicol. 8: 9.

Kroll A, Pillukat MH, Hahn D, Schnekenburger J. 2009. Current in vitro methods in nanoparticle risk assessment: Limitations and challenges. Eur. J. Pharm. Biopharm. 72: 370-377.

Kroll A, Pillukat MH, Hahn D, Schnekenburger J. 2012. Interference of engineered nanoparticles with in vitro toxicity assays. Arch. Toxicol. 86(7): 1123-1136.

Kunzmann A, Andersson B, Vogt C, Feliu N, Ye F, Gabrielsson S, Toprak MS, Buerki-Thurnherr T, Laurent S, Vahter M, Krug $H$, Muhammed $M$, Scheynius A, Fadeel B. 2011. Efficient internalization of silica-coated iron oxide nanoparticles of different sizes by primary human macrophages and dendritic cells. Toxicol. Appl. Pharmacol. 253(2): 81-93.

Laaksonen T, Santos H, Vihola H, Salonen J, Riikonen J, Heikkila T, Peltonen L, Kumar N, Murzin DY, Lehto VP, Hirvonen J. 2007. Failure of MTT as a toxicity testing agent for mesoporous silicon microparticles. Chem. Res. Toxicol. 20(12): 1913-1918.

Landsiedel R, Ma-Hock L, Kroll A, Hahn D, Schnekenburger J, Wiench K, Wohlleben W. 2010. Testing metal-oxide nanomaterials for human safety. Adv. Mater. 22(24): 2601-2627.

Laskar A, Ghosh M, Khattak SI, Li W, Yuan X-M. 2012. Degradation of superparamagnetic iron oxide nanoparticle-induced ferritin by lysosomal cathepsins and related immune response. Nanomedicine 7(5): 705-717.

Laurent S, Burtea C, Thirifays C, Häfeli UO, Mahmoudi M. 2012. Crucial ignored parameters on nanotoxicology: The importance of toxicity assay modifications and "cell vision". PLoS One 7: e29997.

Love SA, Maurer-Jones MA, Thompson JW, Lin YS, Haynes CL. 2012. Assessing nanoparticle toxicity. Annu. Rev. Anal. Chem. (Palo Alto, California) 5: 181-205.

Lynch I, Dawson KA. 2008. Protein-nanoparticle interactions. NanoToday 3(1-2): 40-47.

Maity D, Agrawal DC. 2007. Synthesis of iron oxide nanoparticles under oxidizing environment and their stabilization in aqueous and nonaqueous media. J. Magn. Magn. Mater. 308: 46-55.

Monteiro-Riviere N, Inman A, Zhang L. 2009. Limitations and relative utility of screening assays to assess engineered nanoparticle toxicity in a human cell line. Toxicol. Appl. Pharmacol. 234: 222-235.

Mosmann T 1983. Rapid colorimetric assay for cellular growth and survival: Application to proliferation and cytotoxicity assays. J. Immunol. Methods 65(1-2): 55-63.

Pisanic-II T, Blackwell J, Shubayev V, Fiñones R, Jin S. 2007. Nanotoxicity of iron oxide nanoparticle internalization in growing neurons. Biomaterials 28: $2572-2581$.

Rampersad SN. 2012. Multiple applications of alamar blue as an indicator of metabolic function and cellular health in cell viability bioassays. Sensors 12(9): 12347-12360.

Repetto G, del Peso A, Zurita JL. 2008. Neutral red uptake assay for the estimation of cell viability/cytotoxicity. Nat. Protoc. 3(7): 1125-1131.

Sayes CM, Warheit DB. 2009. Characterization of nanomaterials for toxicity assessment. Nanomed. Nanobiotechnol. 1: 660-670.

Singh N, Manshian B, Jenkins GJS, Griffiths SM, Williams PM, Maffeis TGG, Wright CJ, Doak SH. 2009. NanoGenotoxicology: The DNA damaging potential of engineered nanomaterials. Biomaterials 30: 3891-3914. 
Stephen ZR, Kievit FM, Zhang M. 2011. Magnetite nanoparticles for medical MR imaging. Mater. Today 14(7-8): 330-338.

Stockmann-Juvala H, Naarala J, Loikkanen J, Vähäkangas K, Savolainen K. 2006. Fumonisin B1-induced apoptosis in neuroblastoma, glioblastoma and hypothalamic cell lines. Toxicology 225(2-3): 234-241.

Stone V, Johnston H, Schins RP. 2009. Development of in vitro systems for nanotoxicology: methodological considerations. Crit. Rev. Toxicol. 39(7): 613-626.

Valdiglesias V, Costa C, Kiliç G, Costa S, Pásaro E, Laffon B, Teixeira JP. 2013. Neuronal cytotoxicity and genotoxicity induced by zinc oxide nanoparticles. Environ. Int. 55: 92-100.

Valdiglesias V, Kiliç G, Costa C, Fernández-Bertólez N, Pásaro E, Teixeira JP, Laffon B. 2015. Effects of iron oxide nanoparticles: Cytotoxicity, genotoxicity, developmental toxicity, and neurotoxicity. Environ. Mol. Mutagen. 56(2): 125-148.

Warheit DB. 2008. How meaningful are the results of nanotoxicity studies in the absence of adequate material characterization? Toxicol. Sci. 101(2): 183-185.
Wiogo HT, Lim M, Bulmus V, Yun J, Amal R. 2011. Stabilization of magnetic iron oxide nanoparticles in biological media by fetal bovine serum (FBS), Langmuir 27(2): 843-850.

Wörle-Knirsch JM, Pulskamp K, Krug HF. 2006. Oops they did it again! Carbon nanotubes hoax scientists in viability assays. Nano Lett. 6(6): 1261-1268.

Wu W, He Q, Jiang C. 2008. Magnetic iron oxide nanoparticles: synthesis and surface functionalization strategies. Nanoscale Res. Lett. 3(11): 397-415.

Xiang J-J, Tang J-Q, Zhu S-G, Nie X-M, Lu H-B, Shen S-R, Li X-L, Tang K, Zhou M, Li G-Y. 2003. IONP-PLL: a novel non-viral vector for efficient gene delivery. J. Gene Med. 5(9): 803-817.

Xie J, Jon S. 2012. Magnetic nanoparticle-based theranostics. Theranostics 2: $122-124$.

Yi DK, Lee SS, Papaefthymiou GC, Ying JY. 2006. Nanoparticle architectures templated by $\mathrm{SiO}_{2} / \mathrm{Fe}_{2} \mathrm{O}_{3}$ nanocomposites. Chem. Mater. 18(3): 614-619. 